\title{
Preventing Post-Conflict Terrorism in Poso through Message of Peace: A Case Study of Peace-Striving Khalifah Group
}

\author{
Muhammad Khairil", Raisa Alatas, Dyah Fitria Kartika Sari and Fadhliah
}

\author{
Department of Communication Studies, Faculty of Social and Political Sciences, Tadulako University, \\ Indonesia
}

\begin{abstract}
This study discussed a Peace-Striving Khalifah Group which consisted of several former convicts of terrorism case of Poso conflict. This study used a qualitative approach with case study method. The results revealed that the motivators and the activators of the Peace-Striving Khalifah Group were using a cultural message model at the selfdisclosure stage. The cultural approach was used as a whole. While the psychological approach was not recognized as an initial route by motivators. The ideologies of the former terrorist convicts who were members of the Peace-Striving Khalifah Group were filled with issues of Khilafah, Pancasila, Thaghut and Takfir. One of the conveyed messages models of the group was peaceful-style religious da'wah which included inclusive da'wah messages and respect to the diversity of the people. The role of da'wah brought by the group thought a kind and soothing da'wah which is respected the people.
\end{abstract}

Keywords: Message Construction, Peacemaker Khalifah Group, Terrorism, Post-Conflict, Poso.

\section{INTRODUCTION}

The classification of sentences, in a series of words, into a message, is important for communicators to issue (Corner et al., 2015). Both verbal and non-verbal, messages are the essence of communication to convey a goal and function (Dinică, 2014). Communication in human life is important in which messages within a communication bridge and all forms of ideas and intentions can be conveyed (Khairil, Alatas, et al., 2020). The message is an important element in communication (Freudenstein et al., 2020). If the message is conveyed through the right media using understandable language such as simple words and following the purpose, the message will be easier to convey and will be easier for the communicant to digest. Without messages, there will be no communication (Freudenstein et al., 2020).

In communication, it is very common for a message to have a different meaning from one individual to another. If communication occurs begins with a negative feeling which is then communicated to other people, it will have a negative impact that leads to communication failure. Communication failure can lead to conflict associated with differences in the meaning of the communicant (message recipient). However, errors in the delivery of messages can also cause conflicts (Khairil, 2018a). Conflict is an inseparable part of the socio-political life of society and is often used as a

*Address correspondence to this author at the Department of Communication Studies, Faculty of Social and Political Sciences, Tadulako University, JI. Soekarno Hatta No.KM. 9, Tondo, Mantikulore, Palu City, Central Sulawesi 94148, Indonesia; Tel: +62 823-2121-6664; Fax: 0451 - 422844;

E-mail: mkhairil.untad@gmail.com necessary prerequisite for social change (Fenton, 2014; Khairil, 2017). In its development, communication may very likely be influenced by the value system that applies within the scope of the country where the communication process or message delivery takes place (Batta \& Iwokwagh, 2015). Communication can take place in one direction without a feedback and response system as a reaction to the messages conveyed so that communication is limited to certain problems (Devito, 2011). The reaction that is expected is only in the form of implementation of what is meant in the substance of the communication. There is also a response system that develops in all directions both vertically and horizontally, even multiplying in a multi-flow process (Sukarno, 2014).

In 1998, Poso Regency experienced horizontal conflict for the first time (Khairil, 2017). After the conflict that broke out in 1998 to 2000, several major conflicts were recorded in Poso district. The emergence of the Poso conflict was in line with the emergence of radical groups (Ali, 2016; Purwanto, 2007). The radical groups present were considered to be among those who overshadowed the security of Poso Regency. The remnants of the jihadist society gave birth to radical groups and radical understandings among the community (Karnavian, 2008; Khairil, Yusaputra, et al., 2020).

Dave explained how radicalization in Poso can reach an extreme point when the mujahidin groups spread the ideology of jihad in Poso (Nursahid, 2017). Dave further explained that initially, the mujahidin forged strategic alliances with residents to launch revenge attacks against Christian groups. Dave 
emphasized that the acceptance of a religious agenda will be easily absorbed in the context of the conflict that occurs which not only had a missionary content but also finds momentum. In Poso case, the arrival of the mujahidin coincided with a condition where the desire for revenge by local Muslims was at its peak and when the threat of Christian groups was felt so real. Thus, Dave concludes that radicalization in Poso is in line with Scott Appelby's view, that the ideology of extremist groups will be easily accepted if the conflict conditions are in a defensive stage and if the disseminated interpretations are in line with the life experiences of its followers (Nursahid, 2017).

The Peace-Striving Khalifah Group which is consisted of several former Poso terrorist convicts is a group that was involved in the Poso conflict (Karnavian, 2015). After the court gave the former terrorist convicts free sentences, they did not necessarily eliminate the ideology and ideas which they had embraced so far. The sense of dissatisfaction and injustice that is still ingrained in their minds even after leaving prison can be eliminated through the construction of messages of peace, anti-radicalism, da'wah and even helping from the social side of the Peace-Striving Khalifah Group (Thahir et al., 2018).

Inculcating anti-radicalism messages and education is important to eliminate radical ideology within the group. Deradicalization as an effort to eliminate radicalism that has been embedded in them, including the suspected terrorist families, must be a shared responsibility. For the people of Poso who have experienced conflicts in which many families became victims, it means that radicalism will easily penetrate and be instilled within the community (Khairil, 2018b).

\section{METHODS}

Following the formulation of the problem and the objectives to be achieved, this study is based on a qualitative research approach with a case study method (Arikunto, 2011). The main problem raised in this study concerns the construction of a message of peace in the Peace-Striving Khalifah Group to prevent terrorism after the Poso conflict. Case study research is a qualitative approach that examines real-life cases through detailed and in-depth data collection involving multiple sources of information such as observations, interviews, audiovisual materials and documents from various reports (Cresswell, 2014). The study utilized purposive sampling to obtain the depth of the obtained data (Emerson, 2015). The selection of primary data sources (informants) was carried out simultaneously with the data collection process through snowball sampling technique (Handcock \& Gile, 2011). This decision is done based on the lack of definite and complete data regarding the number and characteristics of sources at the research location in the initial phase of the research. The adequacy of the number of informants is determined based on the adequacy of the necessary research data. The subjects of this research are former terrorist convicts who are members of a Peace-Striving Khalifah Group and mentors. Data analysis in qualitative research begins with preparing and organizing data i.e., text data (transcripts) or image data (photographs) for analysis. Source triangulation techniques is used in order to test the data. Patton stated that this technique puts forward different data sources in testing the truth or validity of data, especially on the same and similar data (Suri, 2011).

\section{RESULT AND DISCUSSION}

\section{Self-Openness Process of Peace-Striving Khalifah Group}

Openness to highly sensitive disclose information must be based on trust. If reciprocity in terms of openness is wanted, then the trust of others must be gained and vice versa (Griffin et al., 2018).Trust is affecting openness which causes the communicant to fully believes in what is conveyed by the message brought by the communicator (Siegelman et al., 2019). At this initial stage, a communicator must understand the communicant before continuing to the next stage. The messages conveyed by the communicator at this stage are also considered important because the message will determine whether the communicator can continue to a closer stage to the communicant. Based on this, the production of messages by communicators and the process of receiving messages by communicants will be seen (Ayres, 1979; Maclntyre, 2019).

Lukman Tahir is a motivator as well as a driving force for Peace-Striving Khalifah Group using a message model that is cultural. The first thing to do when they want to meet their group, Lukman tries to capture language messages based on the unintimate first approach. To be accepted, Lukman Tahir identified what messages could be made to be a part of the group. Therefore, identifying who will I meet is the initial method used by Lukman Tahir as the motivator of the group. 
The motivator then found one of the suspects who carried out the shooting of the prosecutor Ferry Silalahi and began to find out who his parents were which even include his family background to his mother's nickname. After Lukman Tahir found out everything and came back to see him, that topic was brought up. When Lukman mentioned his mother's nickname, the former prisoner began to open up. The symbol which directly touches a child's awareness of his mother is enabling an outsider to understand and makes a more intimate atmosphere.

The psychological approach in a full sense is not fully recognized by the motivator. The motivator prefers to use a cultural approach as a whole. According to Lukman, the beloved nickname for the mother is attached to the culture of Poso, indicating that a person has entered the core of the family. Said entry points are technically recognized as the socio-cultural approach that includes family, school, origin and the personal life of the terror convicts which is entered by Lukman Tahir as the motivator.

According to Lukman Tahir, the method he uses is different from what the government does which in this case is the National Counterterrorism Agency that uses the term deradicalization strategy. According to Lukman, deradicalization is a model for the elimination of ideology as a whole. While Lukman uses a new theory by first taking a socio-cultural approach rather than doing the deradicalization model as an entry point which he argued will not succeed.

The ideology that wants to be removed immediately is an ideological understanding which existed for a long time with this group of former terror convicts. If the ideology of this group is immediately lifted, clash objectives will happen. According to Lukman, these former terror convicts would think who you are to say Islam is peaceful when my families were slaughtered, my sisters had her stomach cut open and the baby was taken out, is that the ideology to be issued?. According to Lukman, anger raged with revenge. Therefore it is not the head but the heart that needed to be entered first. Jhon Horgan refers to it as the process of releasing (Horgan, 2008; Horgan \& Braddock, 2010).

To gain their trust, Lukman tries not to offend the former convicts by labelling them as radicals, terrorists and so on. To get to this stage, according to Lukman as their motivator, is very difficult with the high level of suspicion that existed in this group of former terror convicts.
At this stage, the communicators and communicants show an impression of not to give criticism. People tend to be reluctant to provide evaluations or provide criticism during this orientation stage because it will be judged as inappropriate actions and will disrupt future relationships (Morissan, 2015). Even if there is evaluation or criticism, it will be done subtly. Both parties actively try to avoid becoming involved in a conflict. Thus, they have the opportunity to explore each other in the future. If at this stage those involved feel that they have received enough rewards from the initial interaction, then they will move on to the next stage (Littlejohn et al., 2018).

\section{The Application of Messages of Peace in Socio- Economic Life}

The choice of words or a more personal expression in a message will be more visible at this stage. Even if it is possible if the closeness occurs more quickly in the early stages, changes may occur at this stage more quickly through the forms of the received message (Ayres, 1979).Communication also takes place a little more spontaneously because individuals feel more relaxed with their interlocutors. They will also be less careful in expressing something they will regret later. Touch and emotional expression (such as changes in facial expression) also increase at this stage. This stage is the stage that determines whether a relationship will continue or not (Morissan, 2015). Exchange and exploration through messages will result in transactional and adaptation processes. Adaptation will still be seen from the interaction process of communicators and communicants at this stage (Griffin et al., 2018).

The thoughts and ideologies of the former terror convicts who become members of the Peace-Striving Khalifah Group are filled with the issues of Khilafah, Pancasila, Thaghut and Takfir. This group considers that the government is thaghut and wrongdoer. Those ideologies are what will be eliminated but not by saying that they are radicalized. When the desired ideology has been formed, the message models which is needed to convince the former terror convicts that their ideology was wrong without branding them as radical are included.

One of the conveyed message models is about religious messages of peace including inclusive da'wah messages and preaching that respect the diversity of the people. The role of da'wah brought by the group thought a kind and soothing da'wah which respected 
the people. Even though they have different beliefs, they all lead to goodness.

Habib Ali as one of the religious leaders who also had the opportunity to provide material in the activities of coaching Peace-Striving Khalifah Group helped instill messages of peace. According to Habib Ali, this group was invited to understand how Rasulullah SAW struggled in Medina which was surrounded by Jews and hypocrites and the way that Rasulullah took to face his enemy. Because Rasulullah SAW is the best as an example, any dispute that occurs in this world according to Habib Ali must be returned to Allah and the Prophet, Sirah of the Prophet and the struggle of the Prophet. Habib Ali in the interview said that the Prophet was stung with dirt when in Taif, the Prophet prayed thus, O Allah, guide them, I hope that from them the descendants of people who believe in Allah will be born. Thus, the Prophet is the best role model and example for this group of former terror convicts to follow.

During the coaching process, message models in the form of questions were conveyed by the PeaceStriving Khalifah Group to Habib Ali regarding the current state of Indonesia. Habib Ali then responded by saying Our enemy is not someone else, our enemy is ourselves, we are dealing with ourselves. Habib Ali continued that the inequality of the method did not matter, the important thing was not to not pray. It is our common duty to unite the people. Former terror convicts considered Thaghut as enemy or devil. At the time of the Prophet, the Prophet knew who the hypocrites were and even his friends were told who the hypocrites were. But the Prophet did not dare to shed blood.

After religious messages began to be embedded in the group and answered part of the ideology that had been embedded in them, it is conveyed that jihad was not the only solution. After completing the sentence and getting out of prison, the right course to do is try to start to live amid society again. Members of the PeaceStriving Khalifah Group have their fields of livelihood such as entrepreneurship, teaching or speaking in seminar forums.

According to one of the former terror convicts (informant B) who was part of this training, he said that he was being assisted and helped to understand the ideology aspect and to improve their socio-economic conditions. At this time, informant $B$ has returned to live in Poso and becomes an entrepreneur (supplying sand as a building material). Even though he has unpleasant memories because his family was massacred during the Poso conflict, this did not weaken informant B's intention to live a better life in the future. The message model used in this coaching was suitable for informant $B$ where informant $B$ underwent a process of discussion which is also supported by competent speakers regarding the ideology they believed and their understanding. On the desire of revenge aspect, according to him, the act of shooting the pastor at that time was not wrong because he felt that he was in a state of jihad and would be martyred. After all, he felt wronged as his family was massacred.

Said ideology which was assimilated through majelis in Poso at that time is what the motivators and presenters tried to erase bit by bit. Because, even after the convicts are released from the prison, said ideology is still ingrained within their minds as acknowledged by informant $A$ and $B$. Informant $A$ who felt that his heart was touched by the training of this group and currently a contractor does not want to cut ties with Lukman Tahir and this group. Informant A acknowledged that the ideology of jihad was sticking in his mind to the moment he left prison. It took him a year to make him believe in the approaching model used by Lukman Tahir.

It is not an easy matter to see a brother being slaughtered, the sister having her stomach cut open and her child being taken with your own eyes, and so on as seen by these former terrorist convicts. Wanting to heal these scars on their memories is not an easy thing. Thus, how much is this group willing to build trust to accept, as Lukman pointed out, that you will be on the right path, so let it pass. Now, what is the aim of coaching this Peace-Striving Khalifah Group from a jihadist to a peacemaking hero? To slowly build trust and touch their hearts. The consequence for a motivator, according to Lukman, these former terror convicts will contact to discuss family and economic issues regarding their work at any time.

The effective exchange stage includes a more carefree and relaxed interaction in which communication is often spontaneous and individuals make quick decisions and often paying attention to better overall relationships (Littlejohn et al., 2018). This section focuses on how humans shape meaning in society through conversation. Barbara Ballis Las summed it up to six points. The first is how humans make decisions and act according to their understanding of the situations in which they find 
themselves. Second, social life in which interaction processes are constantly changing. Third, humans who always understand their experiences are found through symbols and language as an important part of social life. Fourth, the world is formed from social objects that have names and meanings in them. The five human actions are always based on their interpretation and finally, others themselves become significant objects and will be introduced through social interactions (Littlejohn et al., 2018).

\section{Peace-Striving Khalifah as the Communicator}

At this last stage, it will be seen whether the initial stage to the stable stage can be passed properly. The communication conveyed by a communicator, of course, carries its function and purpose. Larry A. Samovar explained that delivered communication plays a role in determining and explaining identity, including cultural identity (Samovar \& R., 2010). According to Pittenger, communication can only occur when the communicators use the same sign system. People will not be able to communicate with other people if the language system is different (Devito, 2011).If we want effective communication, it needs to be understood that communication is a transaction. The transaction means that communication is a process, that its components are interrelated and that the communicators act and react as a whole (Devito, 2011).

Through the coaching of this Peace-Striving Khalifah Group, the expected output is not only to improve the socio-economic life of former terror convicts but also to continue the stick of message of peace to their colleagues who are still members of radical groups.Peace-Striving Khalifah Group is currently active in providing materials for antiradicalism seminars. In addition to sharing experiences and the effects of these treatments and changes in them, being a speaker at the seminar also made this an addition to their field of work. According to Lukman, the former terrorists who were members of the PeaceStriving Khalifah Group while in Poso City could enter the deepest lines of the radical groups in Gunung Biru and Tamanjeka of Poso.

Invitational rhetoric is the idea of an invitation both literally and metaphorically as a mode of conversation. For example, if we invite someone to know and see the world from our point of view, this is left to someone or the audience whether to accept or reject the perspective of world that have been introduced to them. Thus, the main goal is to clarify the ideas of all participants (Littlejohn et al., 2018)

\section{CONCLUSION}

In preventing post-conflict terrorism, the message model used is a cultural message approach at an early stage of relationship openness. The psychological approach cannot fully be used in the case of terrorism by the peace-striving khalifah group. socio-cultural approaches, including family, school, origin and personal life of terrorism convicts are the focal point of the problem solving core. The thoughts and ideologies of the former terror convicts who become members of the Peace-Striving Khalifah Group are filled with the issues of Khilafah, Pancasila, Thaghut and Takfir are tried to be eliminated after the initial approach is fulfilled. The novelty in this research is that the message model conveyed is about religious messages of peace including inclusive da'wah messages and preaching that respect the diversity of the people

\section{REFERENCES}

Ali, M. N. (2016). Studi Terorisme di Sulawesi Tengah. Al-Ulum, 16(2), 496. https://doi.org/10.30603/au.v16i2.157

Arikunto, S. (2011). Prosedur Penelitian. Suatu Pendekatan Praktik. Rineka Cipta.

Ayres, J. (1979). Uncertainty and social penetration theory expectations about relationship communication: A comparative test. Western Journal of Speech Communication, 43(3), 192-200. https://doi.org/10.1080/10570317909373968

Batta, H. E., \& Iwokwagh, N. S. (2015). Optimising the Digital Age Health-wise: Utilisation of New/Social Media by Nigerian Teaching Hospitals. Procedia - Social and Behavioral Sciences, 176, 175-185. https://doi.org/10.1016/j.sbspro.2015.01.459

Corner, A., Roberts, O., Chiari, S., Völler, S., Mayrhuber, E. S., Mandl, S., \& Monson, K. (2015). How do young people engage with climate change? The role of knowledge, values, message framing, and trusted communicators. Wiley Interdisciplinary Reviews: Climate Change, 6(5), 523-534. https://doi.org/10.1002/wcc.353

Cresswell, J. W. (2014). Penelitian Kualitatif \& Desain Riset: Memilih di Antara Lima Pendekatan (Terjemahan). Pustaka Pelajar.

Devito, J. A. (2011). Komunikasi Antarmanusia (5th ed.). Karisma Publishing Group.

Dinică, R. C. (2014). Non-verbal Communication-Indispensable Complement of Oral and Written Communication. Procedia Social and Behavioral Sciences, 137, 105-111. https://doi.org/10.1016/j.sbspro.2014.05.260

Emerson, R. W. (2015). Convenience Sampling, Random Sampling, and Snowball Sampling: How Does Sampling Affect the Validity of Research? Journal of Visual Impairment \& Blindness, 109(2), 164-168. https://doi.org/10.1177/0145482X1510900215

Fenton, A. J. (2014). Change and Continuity in Indonesian Islamist Ideology and Terrorist Strategies. Al-Jami'ah: Journal of Islamic Studies, 52(1), 1. https://doi.org/10.14421/ajis.2014.521.1-24 
Freudenstein, F., Croft, R. J., Wiedemann, P. M., Verrender, A., Böhmert, C., \& Loughran, S. P. (2020). Framing effects in risk communication messages - Hazard identification vs. Risk assessment. Environmental Research, 190, 109934. https://doi.org/10.1016/j.envres.2020.109934

Griffin, E., Ledbetter, A., \& Sparks, G. (2018). A First Look at Communication Theory (Tenth Edit). Mc-Graw Hill.

Handcock, M. S., \& Gile, K. J. (2011). Comment: On the Concept of Snowball Sampling. Sociological Methodology, 41(1), 367371.

https://doi.org/10.1111/j.1467-9531.2011.01243.x

Horgan, J. (2008). From Profiles to Pathways and Roots to Routes: Perspectives from Psychology on Radicalization into Terrorism. The ANNALS of the American Academy of Political and Social Science, 618(1), 80-94. https://doi.org/10.1177/0002716208317539

Horgan, J., \& Braddock, K. (2010). Rehabilitating the Terrorists?: Challenges in Assessing the Effectiveness of Deradicalization Programs. Terrorism and Political Violence, 22(2), 267-291. https://doi.org/10.1080/09546551003594748

Karnavian, T. (2008). Indonesian Top Secret; Membongkar Konflik Poso. Gramedia Pustaka Utama.

Karnavian, T. (2015). Explaining Islamist Insurgencies (The Case of Al-Jamaah Al-Islamiyyah and The Radicalisation of The Poso Conflict, 2000-2007). Imperial College Press. https://doi.org/10.1142/p948

Khairil, M. (2018a). Understanding The Perpetrators And Victims of Cyberbullying Through Facebook in The City of Palu. KOMUNIKA: Jurnal Dakwah Dan Komunikasi, 12(1), 158172. https://doi.org/10.24090/komunika.v12i1.1646

Khairil, M. (2018b). Wahdah Islamiyah's Counter-Radicalism Strategy Through The New Media Network in Da'wah Development Of Palu City. Al-Ulum, 18(2), 417-435. https://doi.org/10.30603/au.v18i2.610

Khairil, M. (2017). The Transformation of the Symbolic Meaning of Radicalism in Acts of Terrorism Post-Conflict in Poso Central Sulawesi. International Conference on Democracy, Accountability and Governance, 282-289. https://doi.org/10.2991/icodag-17.2017.55
Khairil, M., Alatas, R., Fitria Kartika Sari, D., \& Mirfath. (2020). Communication Strategy Using Da'wah Assembly to Heal Traumatised Natural Disaster Victims in Palu City. Space and Culture, India, 7(4), 228-233. https://doi.org/10.20896/saci.v7i4.626

Khairil, M., Yusaputra, M. I., Komariah, N., Zakaria, S. Z. S., \& Razman, M. R. (2020). TV One Coverage On The Terrorism Activity Case Of Santoso's Group In Central Sulawesi. Asian Journal of Environment, History and Heritage, 4(1), 103-115.

Littlejohn, S. W., Foss, K. A., \& Oetzel, J. G. (2018). Theories of Human Communication (Eleventh E). Waveland Press Inc.

MacIntyre, P. D. (2019). Anxiety/Uncertainty Management and Communication Accommodation in Women's Brief Dyadic Conversations With a Stranger: An Idiodynamic Approach. SAGE Open, 9(3), 1-18. https://doi.org/10.1177/2158244019861482

Morissan. (2015). Teori Komunikasi Individu Hingga Massa. Kencana.

Nursahid, A. (2017). Radikalisasi dan Deradikalisasi: Belajar dari Konflik Poso.

Purwanto, H. W. (2007). Menggapai Damai di Poso. Cipta Mandiri Bangsa.

Samovar, P., \& R., M. E. (2010). Komunikasi Lintas Budaya (7th ed.). Salemba Humanika.

Siegelman, B., Haenn, N., \& Basurto, X. (2019). "Lies build trust": Social capital, masculinity, and community-based resource management in a Mexican fishery. World Development, 123, 104601. https://doi.org/10.1016/j.worlddev.2019.05.031

Sukarno, B. (2014). Komunikasi Dan Pengendalian Konflik Dalam Politik. Transformasi, 1(26), 1-7.

Suri, H. (2011). Purposeful Sampling in Qualitative Research Synthesis. Qualitative Research Journal, 11(2), 63-75. https://doi.org/10.3316/QRJ1102063

Thahir, I. S., Ihsan, M., \& Hamka, H. (2018). Paradigma Baru Penanganan Terorisme Di Sulawesi Tengah. Istiqro', 13(2), 215-251.

Received on 01-03-2021

Accepted on 31-03-2021

Published on 15-04-2021

https://doi.org/10.6000/1929-4409.2021.10.94

(C) 2021 Khairil et al.; Licensee Lifescience Global.

This is an open access article licensed under the terms of the Creative Commons Attribution Non-Commercial License (http://creativecommons.org/licenses/by-nc/3.0/) which permits unrestricted, non-commercial use, distribution and reproduction in any medium, provided the work is properly cited. 